\title{
The role of economically important traits for genetic improvement and climate change adaptation in livestock production: A review
}

\author{
Kefyalew Alemayehu ${ }^{1}$ and Eyayu Molla ${ }^{1}$ \\ ${ }^{1}$ College of Agriculture and Environmental Sciences, Bahir Dar University, P.O. Box 79, Bahir Dar, Ethiopia
}

\begin{abstract}
Breeding indices include economically important traits associated with high yield, thermal tolerance, low quality feed and disease resistance, and give more consideration of genotype-by-environment interactions to identify stress adapted animals The objective of this paper was to quantify the role of economically important traits for genetic improvement and climate change adapted livestock production. Climate change adaptation genes exist at Protein, the genome (DNA), the transcriptome (RNA), the proteome, Amino-Acid (AA) level .Genotypes that affect milk production traits could be used as genetic markers in marker-assisted breeding. Genes with large effects show part of the genetic differences between animals, and identifying these genes can help to estimate more accurate breeding. For example, polymorphisms in DGAT1, GH and GHR genes have significant effects on reproduction and production traits. The variation in the bovine FABP4 gene also affects milk yield and milk protein content. Growth hormone receptor (GHR), IGF-1 and IGFBP-3 genes regulate postnatal somatic growth and stimulate anabolic processes and showed genetic polymorphisms and associated with production traits in cattle, goats and chickens. In beef cattle, the genes related to economically important traits are peroxisome proliferation activator-y (ppar-y), sterol regulatory element binding protein 1(srebp-1), leptin, stearoyl-coa desaturase (scd1), and thyroid hormone releasing protein. These genes help in lipid and glucose metabolism and in energy homeostasis by promoting glycolsis, lipogenesis and adipo-genesis as well as in regulating body weight, metabolism and reproductive function. Therefore, identifying economically important traits and genes using marker assisted selection related to milk production and beef production can enhance production and productivity.
\end{abstract}

Key words: Cattle, climate smart, economical important traits, performances, markers

DOI: http://dx.doi.org/10.4314/ejst.v10i2.5

\section{INTRODUCTION}

Climate change affects the primary productivity of forage and rangeland productivity, and its significant and visible effects are on feed resources of ruminants. However, the effects significantly differ by location, production system and pasture species (Kefyalew Alemayehu and Tegegn Fantahun, 2012; Kefyalew Alemayehu and Addisu
Getu, 2016). Changes in species composition and breed distribution pattern significantly differ across altitude differ across altitude and agro-ecological variations due to changes in climate-related factors (Kefyalew Alemayehu and Addisu Getu, 2016). Thus, species composition of animals in managed grasslands is an important determinant of livestock productivity. This is because as temperature and $\mathrm{CO}_{2}$ levels change due to climate change, the

\footnotetext{
*Corresponding author: kefyale@gmail.com

(C) This is an Open Access article distributed under the terms of the Creative Commons Attribution License (http://creativecommons.org/licenses/CC BY4.0).
} 
optimal growth ranges for different species also change; consequently, not only species alter their competition dynamics but the composition of mixed grasslands also changes (Thornton et al., 2007).

Economically important traits in farm animals largely consist of complex and continuously distributed phenotypes, which are influenced by multiple polygenes located at quantitative trait loci (Hadecka et al., 2008). Thus the prediction of the future performance of selected animals is one of the most complex tasks in animal breeding (Kovacs et al., 2006). Nowadays, there is great international interest in promoting knowledge about the molecular structure of complex quantitative traits and in directly establishing the genetic merit of the individual (Grisart et al., 2002).

In recent years, significant developments in molecular genetics techniques have been used as an additional tool in conventional livestock breeding and selection strategies (Ardiyanti et al., 2009; Tantia et al., 2006; Oprzadek et al., 2005). As a result, genes or markers that may affect economically important traits of livestock have been identified. There is increasing trend in using a positional candidate gene that affects economically important traits in livestock species, such as fertility, milk, and meat yields (Kovacs et al., 2006; Oikonomu et al., 2008). Several polymorphisms in various genes have been reported to affect production traits in different livestock (Oikonomu et al., 2008).

Genotypes that affect milk production traits could be used as genetic markers in marker-assisted selection programs. Although genes with large effects show part of the genetic differences between animals, identifying these genes could be a great help to estimate more accurate breeding values in breeding programs (Hayes et al., 2009). According to the Mendelian inheritance, in bovine milk six major milk protein fractions $\left(\mathrm{Al}-\mathrm{fa}_{\mathrm{s}}-\mathrm{CN}, \mathrm{Al}-\mathrm{fa}_{\mathrm{s} 2}\right.$ -CN, Kapa-CN, Beta-CN, Beta-LG and AlfaLA) exist in different allelic forms, which are controlled by codominant autosomal genes (Erhardt et al., 1997). This shows that different variants and genetic variability of milk proteins have a significant effect on the physical and chemical properties of milk.

In dairy animals, growth and reproduction are two key traits to be considered for genetic improvement and production efficiency. Genetic markers for quantitative trait loci that are linked to the causal genes could be used to select animals for breeding programs. The most effective markers are the functional mutations linked to the trait genes. Identification and use of markers for milk quality and production traits, disease resistance and thermo-tolerance would ensure better health and productivity (Singh et al., 2014).

On the other hand, in the beef cattle industry multiple genes including calpastatin and thyroglobulin are known to have effect on meat quality (Zhang et al., 1993). Among the traits that are important in determining bovine meat quality, tenderness stands out as the principal desirable attribute for the final consumer. The calciumdependent proteolytic system has been considered as one of the greatest factors responsible for variations in extension of post-mortem tenderizing (Koohmaraie, 1994) and is characterized by three components: one enzyme that requires low calcium concentration (1-calpain), another requiring high concentration of the same one (m-calpain) and calpastatin, a specific inhibitor of calpains. Thus, the genes coding for 1-calpain 
(CAPN1) and calpastatin (CAST), located on bovine chromosomes 29 and 7, respectively, are considered strong functional candidates for meat tenderness in meat producing animals.

The aim of selection and breeding is to improve the use value of animal genetic diversity and its economically important traits. Climate change projections suggest that additional selection of breeds with effective thermoregulatory control is necessary to mitigate and adapt the impacts of climate change (Hoffmann, 2010). Therefore, the objective of this paper was to quantify the role of economically important traits for genetic improvement and climate change adaptation in livestock production.

\section{Climate change adaptation at genomic level}

Heat stress is known to alter the physiology of livestock, to reduce male and female reproduction and production, and to increase mortality. Livestock water requirements increase with temperature. Heat stress suppresses appetite and feed intake; thus, feeding rations for highperforming animals need to be reformulated to account for the need to increase nutrient density (Kefyalew Alemayehu and Damite Kebede, 2015). Body temperatures beyond $45-47{ }^{\circ} \mathrm{C}$ are lethal in most species. Nowadays, heat stress is an important factor in determining specific production environments while the vulnerability of livestock to heat stress varies according to species, genetic potential, life stage and nutritional status. Specifically increasing intensification of dairy systems in the developing world through the use of temperate-breed genetic stock could lead to greater vulnerability to increasing temperatures (Thornton et al., 2009). The ability to thermoregulate depends on complex interactions among anatomical and physiological factors (Hall, 2004). With increasing milk yield in dairy cattle, growth rates and leanness in pigs or poultry metabolic heat production has increased, and the capacity to tolerate elevated temperatures has declined (Zumbach et al., 2008; Dikmen and Hansen, 2009). Therefore, in the long term single-trait selection for yields will result in animals with lower heat tolerance. This indicates the effect of heat stress on milk yield at specific test days is more immediate and easier to measure than growth (Zumbach et al., 2008). In general, high output breeds originating from temperate regions that provide the bulk of market production today are not well adapted to heat stress. Milk production, fertility and longevity in Holstein Friesian cattle, for example, decline as temperature increases (St- Pierre et al., 2003). On the other hand, many species and local breeds, particularly those from the near East and Africa, are already adapted to high temperatures and harsh conditions (Steinfeld et al., 2006).

Selection for tolerance to environmental stress has traditionally resulted in reduced productivity. Acclimation to heat stress is a homothetic process, which involves changes in hormonal signals that affect target tissue responsiveness to environmental stimuli. Improving understanding of this process will lead to improved genetic selection of heat stress resistant genotypes. Among the genetic adaptations that have developed in zebu cattle during its evolution have been the acquisition of genes for thermotolerance i.e. cattle from zebu breeds are better able to regulate body temperature in response to heat stress than are cattle from a variety of $B$. taurus breeds of European origin (Gaughan et al., 2000). Genetic differences in thermotolerance extend to the cellular level as well because deleterious effects of elevated temperature on cellular function are less for cells from Brahman 
cattle than cells from Angus and Holstein (PaulaLopes, 2003).

\section{Adaptation at the genome (DNA) level}

The thermal denaturation of double-stranded DNA molecules is affected by their nucleotide composition (Russell and Holleman, 1974). The expectation is that the genomes of organisms growing at higher temperature would be subject to selection for a higher proportion of $\mathrm{G}+\mathrm{C}$ than $\mathrm{A}+\mathrm{T}$, because of the increased number of hydrogen bonds between $\mathrm{G}$ and $\mathrm{C}$ than $\mathrm{A}$ and $\mathrm{T}$ on complementary strands (Kefyalew Alemayehu and Damite Kebede, 2015). Thermophilic organisms have mechanisms other than increasing $\mathrm{G}+\mathrm{C}$ content for maintaining the double-stranded structure of their DNA at high temperatures. This possibly is due either to the existence of thermophile-specific enzymes, such as the reverse gyrase, or to the selection for certain dinucleotides that may contribute to thermostability (Nakashima et al., 2003; Paz et al., 2003).

\section{Adaptation at the transcriptome (RNA) level}

The transcriptome includes both the structural RNAs (such as ribosomal and transfer RNAs, rRNAs and tRNAs) and the protein-encoding messenger RNAs. One could argue that these molecules, especially the structural RNAs, would be subject to the same temperature-dependent constraints as DNA. Galtier and Lobry (1997) revealed that there is a significant correlation between the $\mathrm{G}+\mathrm{C}$ content of structural RNAs and growth temperature. The high $\mathrm{G}+\mathrm{C}$ content is concentrated in the double-stranded stem regions of the molecule. This provides strong evidence for selection acting to increase the thermostability of these regions by changing the nucleotide composition. The expected correlation between nucleotide content and growth temperature in the paired regions of an RNA molecule (but not in double-stranded DNA) might be due to the fact that single mutations affecting nucleotide composition. This might have have a much greater effect on the stability of the stem regions of an RNA molecule than they do on double-stranded genomic DNA. This is simply because the length of the paired region is much shorter in the RNA molecule (Paz et al., 2004).

\section{Adaptations at the proteome, Amino-Acid (AA) level}

Most of the proteome-based studies to date have focused on the average amino-acid (AA) composition of proteins in the proteomes of mesophiles and thermophiles. If the protein structure is determined to a large extent by the primary amino-acid sequences, then the differences in amino-acid composition between the proteins of thermophiles and mesophiles can be observed. Such differences have been reported for individual genes and in whole-genome comparisons (Farias and Bonato, 2003). The average amino-acid composition of a given proteome is dramatically affected by the underlying patterns of genomic nucleotide bias (Wang et al., 2004). The major effect of thermophily at the proteome level was a significant reduction in the frequency of the thermolabile amino acids histidine, glutamine and threonine (Singer and Hickey, 2003). The concomitant increase, among thermophiles, of both positively charged residues (arginine and lysine) and negatively charged residues (glutamic acid) suggests that ionic bonds between oppositely charged residues may help to stabilize multimeric proteins at high temperature. 


\section{Adaptation at protein level}

Heat adaptation is divided into thermotolerance and acclimatization. Thermotolerance is a cellular adaptation caused by a single, severe but non-lethal heat exposure that allows the organism to survive a subsequent and otherwise lethal heat stress. In contrast, acclimatization is an organism's ability to perform increased work in the heat because of improvements in heat dissipation brought on by repeated mild elevations in core temperature. Central to understanding thermotolerance and perhaps to the cellular role in acclimatization are the heat shock or stress proteins (HSPs). The HSPs have been studied for their regulation, localization, and function in the cell. They range in size from 27 to $110 \mathrm{kDa}$ and can be divided into five groups based on both size and function. Initially, stressinduced HSP accumulation is associated with thermotolerance, the ability to survive otherwise lethal heat stress, and later with tolerance to a variety of stresses. The fact that over expression of various HSPs confers tolerance in the absence of conditioning stress and that inhibition of HSP accumulation through blocking antibodies impairs stress tolerance strongly support the hypothesis that HSPs themselves confer the stress tolerance. HSP70 and HSP60 perform a unique relay in the movement of cellular proteins through the mitochondrial membrane, with HSP70 transporting the protein to the outer mitochondrial membrane and participating in the protein's unfolding and insertion into the membrane. HSP60 accepts the protein and participates in the refolding of the protein within the mitochondria (Deshaies, 1988). Thermotolerance refers to an organism's ability to survive an otherwise lethal heat stress from a prior heat exposure sufficient to cause the cellular accumulation of HSPs. Regardless of stimuli, the whole marks of thermotolerance are survival of the cell or organism exposed to an otherwise lethal heat stress; synthesis of HSPs; and a relatively short duration of the thermotolerant state (hours to days) that correlates with the presence of elevated cellular HSPs and declines with the decrease in HSPs. The requirement of HSPs for thermotolerance and the role of HSPs in protein folding assembly and transport support the hypothesis that the thermotolerant state is dependent on one or all of these HSP-related functions, especially through the management of both denatured proteins and partially synthesized protein fragments.

\section{Adaptations during Hibernation}

Many small mammals use hibernation to escape from the cold temperatures and scarcity of food that accompany winter in temperate and polar climates. By strongly suppressing metabolic rate and allowing body temperature $(\mathrm{Tb})$ to fall to near ambient, many species can survive for 6-9 months living off huge body fat reserves. Reorganization of gene expression to benefit heart function during hibernation may be expected, and the changes in protein products that result may, in fact, define the difference between the endurance of deep hypothermia by hibernating mammals and the lethal effects that equivalent hypothermia exposure has for most mammals, including humans. Screening of a cDNA library made from heart of hibernating ground squirrels with 32P-labeled single-stranded cDNA probes prepared from mRNA of euthermic vs hibernating animals isolated two clones; these were then confirmed as up-regulated during hibernation via northern blots (Fahlman et al., 2000). After sequencing and similarity search in Genbank, one clone was identified as the nuclear gene $M L C 1 v$ which encodes the ventricular isoform of 
myosin light chain subunit 1 (MLClv). The other was a mitochondrial gene (Nad2) which encodes subunit 2 of NADH ubiquinone oxidoreductase (ND2), a protein of the electron transport system. The hibernation-induced up-regulation of $\mathrm{Nad} 2$ transcripts is harder to explain but stress-induced changes in transcript levels of mitochondrially encoded subunits of electron transport chain proteins, including ND, are found in various animals and cell lines. This suggests that changes in subunit composition of these multi-subunit complexes may serve adaptive or functional needs. It appears, then, that increased transcription of mitochondrial genes can be a response to either hypothermia or hypoxia.

\section{Economically important traits in dairy cattle}

\section{The effects of polymorphisms in DGAT1, GH} and GHR genes on reproduction and production traits in dairy cattle

The genetic selection aiming solely at increased milk yield has led to decreased reproduction efficiency as well as greater incidence of mastitis and other diseases in dairy cattle. The declined health and fertility are thought to be associated with the negative energy balance (NEB) resulting from insufficient demands of high milk production dietary energy intake (Wathes et al., 2007). It seems justified to presume that genes affecting milk yield and composition may also alter the calorific demand for milk production and influence the severity and duration of NEB in early lactation. Thus, their polymorphism may be associated with the reproductive traits variation.

The acyl-CoA, diacylglycerol acyltransferase (DGAT1) and growth hormone receptor (GHR) are examples of such genes. DGAT1 encodes an enzyme playing the key role in synthesis of triacylglycerol, the major milk lipids (Farese et al., 2000). An ApA to $\mathrm{GpC}$ dinucleotide substitution located in exon 8 of DGAT1that replaces positively charged lysine by neutral alanine at the $232^{\text {th }}$ residue of the encoding protein (K232A polymorphism) has been proved to have a pronounced effect on milk-related traits in cattle, especially on production of fat the most energetically expensive component of milk to synthesize (Kaupe et al., 2007; Näslund et al., 2008). An F279Y polymorphism (a non conservative $\mathrm{T}$ to A replacement resulting in the phenylalanine to tyrosine change at position 279) in exon 8 of bovine GHR gene was also found to be significantly associated with milk yield and composition (Blott et al., 2003).

\section{Variation in the bovine FABP4 gene affects milk yield and milk protein content in dairy cows}

Fatty acid binding proteins (FABPs) bind longchain fatty acids and transport them within cells. They have also been implicated in lipid metabolism, in the expression of fatty acidresponsive genes and in the maintenance of cell membrane fatty acid levels. There are nine known members of the FABP gene family (FABP1-FABP9), and they are differentially expressed in different tissues (Chmurzynska, 2006). In the bovine mammary gland, the most abundant FABP mRNAs are for FABP3, FABP4, and FABP5; and for all, gene expression is greatly up-regulated during lactation. FABP4 has been mapped to BTA14 (Michal et al., 2006) in a location $(46,833,665-46,838,053)$ that is rich in quantitative trait loci (QTL) for milk production traits (Ogorevc et al., 2009). 
Marchitelli et al. (2013) found that FABP4 influenced both medium chain and long chain fatty acid (FA) levels in milk and suggested FABP4 was the "most important" gene affecting milk fat composition out of the nine candidate genes. Similarly, Nafikov et al. (2013) reported that certain FABP4 haplotypes were associated with particular fatty acid profiles in milk but found no differences in milk yield.

\section{Genetic variability of bovine GHR, IGF-1 and IGFBP-3 genes in dairy cattle}

Molecular techniques such as polymerase chain reaction-single strand conformation polymorphism (PCR-SSCP) are effective tools in the animal breeding domain for providing breeders an opportunity to identify and select superior animals based on genotypes associated with particular traits of interest (Bastos et al., 2001). Growth hormone receptor (GHR), IGF-1 and IGFBP-3 genes have been shown to regulate postnatal somatic growth and stimulate anabolic processes (Clemmons et al., 1987). Growth hormone (GH) is an anabolic hormone synthesized and secreted by the somatotroph cells. It plays an important role in postnatal longitudinal growth and development, tissue growth, lactation, reproduction, and protein, lipid and carbohydrate metabolism (Thidar et al., 2008). Earlier research on GHR, IGF-1 and IGFBP-3 in cattle, goats and chickens showed genetic polymorphisms and their association with production traits (Liu et al., 2010).

GHR genes are important candidates for growth, carcass and milk traits in dairy cattle. This was shown by different researchers. A significant correlation was found between the PI promoter of the bovine GHR gene and growth rates in young Angus cattle (Hale et al., 2000). Biswas et al. (2003) identified $\mathrm{GH}$ gene polymorphism in intron4 / exon5 and its effect on birth weight in different breeds of cattle and buffalo. Rahbar et al. (2010) found polymorphism in the promoter region of the GHR gene and an association with milk-related traits in Holstein cows. Mullen et al. (2011) identified a total of 16 SNPs in IGF-1 and $\mathrm{GH}$ gene and its association with milk production, body condition score and fertility traits in Holstein Friesian lactating dairy cows.

\section{Peroxisome proliferator-activated receptor gamma co activator 1 alpha (PPARGC1A)}

Candidate genes for economically important traits are selected based on linkage as well as biological functions in cattle and other species. Such knowledge may be important for genetic selection as well as disease prevention. Bovine PPARGC1A (also known as PGC-1) is located in chromosome 6 and consists of 13 exons (Weikard et al., 2005). Several polymorphisms were identified within this gene (Schennink et al., 2009; Soria et al., 2009).

On the other hand, PPARGC1A is involved in mammary gland metabolism, and the expression of PPARGC1A is correlated with milk fat content (Bionaz and Loor, 2008). Recently, it was shown that PPARGC1A co-activates the steroidogenic factor 1 to influence progesterone production in ovarian granulose cells (Yazawa et al., 2010) and to increase the secretion of LH in pituitary (Zhu et al., 2010).

\section{CYP11B1 (cytochrome P450 family 11 subfamily}

\section{B hydroxylase)}

There are several indications that CYP11B1is a positional and functional candidate gene for milk production traits. CYP11B1 influences the production of cortisol, androgen function and ultimately the proliferation of milk gland 
cells (Brettes and Mathelin, 2008). The bovine CYP11B1gene is positioned in chromosomal region BTA14q12 (Kaupe et al., 2004) near marker ILSTS039. This marker is associated with milk yield as well as with milk component yields (Wibowo et al., 2008).

\section{PRL (prolactin gene)}

PRL is a polypeptide produced not only by the pituitary gland but also by the mammary gland. This hormone has over 300 functions. It is involved in water and electrolyte balance, growth and development, endocrinology and metabolism, behavior, reproduction and immuno regulation. It plays a crucial role in mammary gland development and lacto genesis.

\section{Polymorphic sites within a Bov-A2 element} in the promoter region of the steroid 21-hydroxylase gene in cattle

The CYP21gene is a member of the CYP gene family and encodes the steroid 21-hydroxylase (P450c21) enzyme connected with the microsomal P450 cytochrome. It is essential to corticosteroid metabolism and involved in steroid genesis in the adrenal cortex. Especially, Bovine CYP21 can be considered as a candidate gene due to several quantitative trait loci (QTL) for reproduction (Szatkowska et al., 2011) and production traits (Jedrzejczak et al., 2011; Silva et al., 2011). The bovine CYP21 gene containing 10 exons was mapped on chromosome 23 and is highly polymorphic in different local cattle breeds.

\section{Effect of polymorphisms at the STAT5A and} FGF2 gene loci on reproduction and milk yield cows

The possible impacts of the signal transducer and activator of transcription 5A (STAT5A) and fibroblast growth factor 2 (FGF2) genes are on dairy cows' production and fertility traits. Polymorphisms in the STAT5A gene have been associated with cows' production traits and particularly a single nucleotide polymorphism (SNP12195) in exon 8 of the STAT5A gene (a G-to-C substitution) was found to affect milk protein and fat percentage, as well as in vitro embryonic survival and fertilization rate (Khatib et al., 2009). The FGF2 gene regulates trophectoderm expression of interferon which is the maternal pregnancy recognition factor in ruminants (Michael et al., 2006). Thus, this gene is also a candidate gene that may affect cows' fertility. Khatib et al., (2009) reported the association of FGF2 gene within vitro embryonic survival and fertilization rate in cattle by investigating the SNP11646 (an A-to-G substitution) in introns 1 of FGF2gene.

\section{Leptin Receptor (LEPR) gene}

The LEPR gene is located on BTA 3. It is a member of the cytokine I family of receptors and signal transducers. Previous studies have identified the LEPR gene to be expressed in a variety of tissues in ruminants including the mammary glands and liver (Bartha et al., 2005). In ruminants, expression of the LEPR gene is affected by an animal's level of nutrition (Chilliard et al., 2005). Additionally, blood Leptin concentrations interfere with luteinizing hormone secretion and stimulate growth hormone release (Kadokawa et al., 2006; Nonaka et al., 2006). In both beef and dairy breeds the LEPR gene polymorphisms have been described as affecting milk yield, live weight, feed intake, and fertility. These associations may provide insight into the underlying mechanisms of this gene and results could be utilized in future breeding programs (Almeida et al., 2008). 


\section{Calpastatin (CAST) gene}

CAST is an endogenous and specific inhibitor of m-calpain and $\mu$-calpain and is involved in the degradation of myofibrillar proteins in postmortem proteolysis, which directly affects postmortem meat tenderness (Casas et al., 2006). The calpain-calpastatin system has been described to increase the rate of skeletal muscle growth as a result of decreased muscle protein degradation. The process of decreased muscle protein degradation has previously been shown to be directly associated with an increase in CAST gene expression (Kubiak et al., 2008).

Calpastatin is a protein encoded by the CAST gene located on BTA7 (Raynaud et al., 2005). Garcia et al. 2006, identified mutation in the CAST gene associated with daughter pregnancy rate (DPR) in Holstein cattle. The predicted transmitting ability for DPR was +0.13 for the wild type genotype, -0.44 for the heterozygous genotype, and -0.69 for animals that were homozygous for the mutant genotype. Identification of genetic mutations such as this has the potential or direct selection of animals possessing gene variants superior for both milking ability and fertility.

\section{The impact of Kappa casein gene polymorphism on milk ccomponents}

The bovine milk specific proteins include casein four genes vis: $\alpha$ s1-, $\beta-, \alpha s 2$ - and $\kappa$-casein (CSN1S1, CSN2, CSN1S2 and CSN3, respectively) producing approximately 80 percent of the protein content of cow's milk (Farrell et al., 2004). These proteins and their genetic variants have been widely investigated and considered as an important factor associated with lactation performance, milk composition and cheese yield efficiency. The casein genes are tightly linked and inherited as a cluster, so they have a potential value and can play an important role in marker-assisted selection for milk traits. The bovine $\kappa-\mathrm{Cn}$ gene possesses 5 exons distributed over approximately $13 \mathrm{~kb}$ of the bovine genome (Martin et al., 2002). According to Hamza et al. (2010) K-Cn genotypes had significant effect on fat, protein and lactose content, but it did not affect either TS or SNF. Moreover, the study detected that cows with genotype TT had higher fat and protein contents than those of genotypes CC and TC.

\section{The bovine breast cancer 1 gene (BRCA1)}

The bovine BRCA1 gene has been mapped to chromosome 19 (BTA19). This location was within a region of similar gene order as the BRCA1locus in human (chromosome 17) and mouse (chromosome 11) (Krum et al., 2003). It was also located within or nearby the genomic region of SCS QTL (Daetwyler et al., 2008). Furthermore, Krum et al., (2003) reported that the bovine BRCA1 sequence is a better predictor of disease alleles (versus polymorphisms) than either the murine or the canine sequences. However, BRCAlgene poly-morphisms associated with bovine mastitis in various cattle breeds have not been investigated to date; therefore, the BRCA1 gene is considered to be one of the potential candidate genes influencing SCS and mastitis.

\section{Economically important traits in beef cattle}

The genes related to economically important traits in beef cattle are peroxisome proliferation activator-y (ppar-y), sterol regulatory element binding protein 1(srebp-1), leptin, stearoyl-coa desaturase (scd1), and thyroid hormone releasing protein. 
Peroxisome proliferation activator receptors $-\mathbf{y}$ (PPARy)

PPARy is a transcription factor that modulates lipid and glucose metabolism in mammals. It is expressed in many cell types including adipocytes, epithelial cells, endothelial cells, smooth muscle cells as well as many tissues (Clark et al., 2000). The fat content in cattle may, therefore, be regulated by the PPARy transcription factor in a depot specific manner.

\section{Leptin gene}

Leptin is a protein hormone with important effects in regulating body weight, metabolism and reproductive function (Schenkel et al., 2006a). The role of leptin is a lipo statical signal regulation. The whole body energy metabolism makes it one of the best physiological markers of body weight, feed intake and energy expenditure (Schenkel et al., 2005), reproduction (Cunningham et al., 1999) and certain immune functions (Lord et al., 1998). In cattle the leptin gene has been mapped to bovine chromosome 4. Polymorphisms in the coding region of the leptin gene in cattle have been associated with body fatness (Pannier et al., 2010).

\section{Stearoyl- CoA Desaturase1 (SLD)}

SLD is associated with increased fat accumulation and mono unsaturated fatty acids in skeletal muscle. It is a rate limiting enzyme that catalyzes the synthesis of mono unsaturated fatty acids which are components of triglycerides, wax esters, cholesters and membrane phospholipids (Miyataki and Ntamrane, 2003), The gene is highly expressed in white adipose tissue as well as brown adipose tissue under normal dietary conditions (Jiang et al., 2008).The mammalian SDL gene isolated in several species including mouse, cattle and human shows conserved genomic structure spanning approximately $15-24 \mathrm{~kb}$ and consisting of six exons and five introns (Milanesi et al., 2007).

\section{Corticotrophin releasing hormone (CRH) gene}

$\mathrm{CRH}$ gene is a stress hormone released by the anterior pituitary gland to stimulate the secretion of adrenocorticotrophic (ACTH) which regulates cortisol. Cortisol has many significant metabolic effects that include stimulating gluconco genesis in liver inhibiting glucose uptake in muscle and adipose tissue as well as in stimulating fat breakdown in adipose tissue. It is a good positional candidate gene for fat related traits (Buchanan et al., 2005)

\section{Fatty acid binding protein4 FABP4 and DGAT1 genes}

DGAT1 genes are associated with intramuscular fat (IMF) levels or marbling scores in beef. They were identified to be genetic factors influencing intramuscular fat deposition in muscle (Michal et al., 2006). Different studies revealed that DGAT1 gene was significantly associated with fat related traits such as back fat thickness and marbling in beef cattle and fat content as well as composition in dairy cattle (Schennink et al., 2007)

\section{Association between polymorphism of MyF-5 gene with meat quality traits}

Differences in meat quality are probably due to the variation in different genetic and ecological factors which interact and determine the course of metabolic reactions in muscle tissue and also in the postmortem conversion of muscles to meat. 
A candidate gene access may furnish a more channeled understanding of the genetic basis for the manifestation of quantitative divergences between individuals (Nogurera, 2003).

Myogenesis is a multi-dimensional process involving commitment, proliferation, and specification during embryo growth maturation and function, and it is chiefly controlled by myogenic determination (MyoD) gene family. Myogenic factor 5 (MyF-5) has been fine mapped for QTLS for birth weight, pre weaning average daily gain and average daily gain on cattle chromosome 5 (Li et al., 2010). Three chromosomal regions (0 to $30 \mathrm{cM}, 55$ to $70 \mathrm{cM}$, and 70 to $80 \mathrm{cM}$ ) that are significantly associated with carcass and meat quality traits were disclosed. The role of MyF5 and MyF-6 are considered to be inherent for innovation and growth of straight muscle and to the sustainment of its physical appearance. Hence, they are believed to be candidate genes for growth and meat quality characters (Maak et al., 2006; Verner et al., 2007).

\section{Genetic polymorphisms at the leptin receptor gene in beef cattle breeds}

Low bovine fertility rate is associated with suboptimal nutrition and is a major concern of livestock cattle production systems. Recently, much effort has been devoted to understand the role of the leptin protein and its receptor in regulating food intake and reproduction in ruminants (Chilliard et al., 2005). Leptin is secreted by adipose tissues and acts especially through its receptor on the hypothalamus (the center of energy homeostasis), on ovarian follicular cells and on placenta and lactating mammary glands (Bartha et al., 2005; Chilliard et al., 2005).
In ruminants, LEPR expression seems to be affected by high and low nutrition levels (Chilliard et al., 2005) while blood leptin concentrations seem to interfere in luteinizing hormone secretion (Kadokawa et al., 2006) and to stimulate growth hormone release (Nonaka et al., 2006). In cattle, as in other mammalian species, there is a positive relationship between circulating leptin and fat content (Murdoch et al., 2005). Leptin also seems to play a role in reproduction (Kendall et al., 2004; Kadokawa et al., 2006). Leptin action is mediated by the leptin receptor protein, and LEPR mRNA abundance is increased by acute food restriction (Murdoch et al., 2005). Therefore, the analyses of the leptin receptor gene polymorphisms could be useful to understand the reproductive performance and weight gain variations in cattle.

\section{The calpastatin and thyroglobulin gene polymorphisms in cattle breeds}

In the beef cattle industry, multiple genes, including calpastatin and thyroglobulin, are known to have effect on meat quality (Zhang et al., 1993). It has been reported that the effect of the calpastatin gene (CAST) on meat tenderness is determined by measuring the Warner-Bratzler shear force (WBS) value. Calpastatin, which is an endogenous calpain inhibitor, plays a key role in the regulation of calpain activity in the cell and does not inhibit proteases other than calpain. Calpastatin affects meat tenderness indirectly through its effect on calpain. Calpastatin, alongside calpain, is found in the cytosol and cell membrane. Calpastatin contains four inhibitory regions where one molecule of calpastatin inhibits four molecules of calpain (Barendse et al., 2007). It has been reported that CAST indirectly enables the post-mortem breakdown of the myofibrillar proteins through its involvement in the regulation 
of the activity of calpain, which leads to the proteolysis of the myofibrils (Pareekes et al., 2008). The thyro globulin gene (TG) encodes the thyro globulin protein, which acts as the precursor of triiodothyronine and tetra iodothyronine and is involved in the development of adipocytes (Ailhaud et al., 1992). For a long time, it has been known that thyroid hormones are involved in the deposition of fat between myocytes. It has been suggested that, in cattle, a polymorphism detected in the 5 UTR- untranslated region of the TG gene alters the transcriptional and translational activities of the gene. In cattle, this polymorphism has been demonstrated to affect the marbling score, a meat quality character.

\section{CONCLUSION}

From this review it is possible to see that selection and breeding helps to improve the performances of indigenous animal genetic resources. Selection of indigenous cattle and breeding for dairy and beef production has paramount importance since the cattle possess economically important dairy associated traits. Improving indigenous breeds towards milk production will help to have sustainable production as they do have the capacity of adapting climate related factors, thermal tolerance, survival with low quality feed and disease resistance. Thermal tolerance in livestock exists at protein, the genome (DNA), the transcriptome (RNA), the proteome, Amino-Acid (AA) level. The productive and reproductive performance of dairy cattle is affected or governed by more than one gene such as DGAT1, GH, GHR, STAT5A and FGF2 gene and others. Most of the beef cattle economical traits are affected by genetic factors than environment and are governed by many gene interactions. Therefore, indigenous cattle have genes with many economical values, and selection should be done using genetic markers so as to increase production and productivity with adaptation of environmental challenges.

\section{REFERENCES}

Ailhaud, G., Grimaldi, P and Negrel, R. (1992). Cellular and molecular aspects of adipose tissue development. Cellular and molecular aspects of adipose tissue development Annual Review of Nutrition 12:207-33.

Ardiyanti, A., Oki, Y., Suda, Y., Suzuki, K., Chikuni, K., Obara, Y and Katoh, K. (2009). Effects of GH gene polymorphism and sex on carcass traits and fatty acid compositions in Japanese Black cattle. Animal Science Journal 80: 62 69.

Barendse, W., Harrison ,B.E., Hawken, R.J., Ferguson, D.M., Thompson, J. M., Thomas, $\mathrm{M}$ and Bunch, R..J. (2007). Epistasis between Calpain 1 and its inhibitor Calpastatin within breeds of cattle. Genetics 176:2601-2610.

Bartha, T., Sayed-Ahmeda, A and Rudas, P. (2005) Expression of leptin and its receptors in various tissues of ruminants. Domestic Animal Endocrinology 29:193-202.

Bastos, E., Alfredo, C., Azevedo, J and Pinto, H.G. (2001). Single strand conformation polymorphism (SSCP) detection in six genes in Portuguese indigenous sheep breed "Churrada Terra Quente". Biotechnology Agronomy and Social Environments 5 (1): 7-15. 
Bionaz, M and Loor, J. J. (2008). ACSL1, AGPAT6, FABP3, LPIN1, and SLC27A6are the most abundant isoform in bovine mammary tissue and their expression is affected by stage of lactation. Journal of Nutrition 138: 1019-1024.

Biswas, T.K., Bhattacharya, T.K., Narayan, A.D., Badola, S., Kumar, P and Sharma, A. (2003). Growth hormone gene polymorphism and its effect on birth weight in cattle and buffalo. Asian Australian Journal of Animal Sciences 16: 494-497.

Blott, S., Kim, J.J., Moisio, S., Schmidt-Küntzel, A., Cornet, A., Berzi, P., Cambisano, N., Ford, C., Grisart, B., Johnson, D., Karim, L., Simon, P., Snell, R., Spelman, R., Wong, J., Vilkki, J., Georges, M., Farnir, F and Coppieters, W. (2003). Molecular dissection of a quantitative trait locus: a phenylalanine-to-tyrosine substitution in the trans membrane domain of the bovine growth hormone receptor is associated with a major effect on milk yield and composition. Genetics 163: 253-266.

Brettes, J.P and Mathelin, C. (2008). Effete dual des androgens surla glande mammaire. Bulletin $d u$ Cancer (Paris) 95: 495-502.

Brymp P, Kaminski S and Wojcik E. (2005). Nucleotide sequence polymorphism within exon 4 of the bovine prolactin gene and its associations with milk performance traits. Animal Genetics 45(2): 179-85.

Buchanan,F.C., Fitzsimmons, C.J., vankessel, A.G., Thue, T.D., Sim,D.C.W and Schmitz S.M. (2002). Association of a missense mutation in the bovine leptin gene with carcass fat content and leptin MiRNA levels. Genetic Selection Evolution 34 (1): 105-116.

Casas, E.S.N., White, T.L., Wheeler, S.D. Shackelford, M., Koohmaraie, D.G., Riley, C.C., Chase, J.R., Johnson, D.D and Smith,
T.P.L. (2006). Effects of calpastatin and $\mu$-calpain markers in beef cattle on tenderness traits. Journal of Animal Sciences 84: 520-525.

Chilliard, Y., Delavaud, C and Bonnet, M. (2005). Leptin expression in ruminants: Nutritional and physiological regulations in relation with energy metabolism. Domestic Animal Endocrinology 29: 3-22.

Chmurzynska, A. (2006). The multigene family of fatty acid-binding proteins (FABPs): function, structure and polymorphism. Journal of Applied Genetics 47: 39-48.

Clark, R.B., Bishop-Bailey, D., Estrada-Hernandez T., Hla, T., Puddington, L and Padula, S.J. (2000). The nuclear receptor PPAR and immuno regulation: PPAR mediates inhibition of helper $\mathrm{T}$ cell responses. Journal of Immunology 164: 1364-1371.

Clempson, A. M., Pollott, G. E., Brickell, J. S., Bourne, N. E., Munce N and Wathes, D.C. (2011). Evidence that leptin genotype is associated with fertility, growth, and milk production in Holstein cows. Journal of Dairy Sciences 94: 3618-3628.

Cunningham, M.J.,Clifton, D.K and Steuner, R.A. (1999). Leptin actions on the reproductive axis: Perspective and mechanisms. Biology and Reproduction 60: 216-222.

Daetwyler, H.D, Schenkel, F.S., Sargolzaei, M and Robinson, J.A. (2008). A genome scan to detect quantitative trait loci for economically important traits in Holstein cattle using two methods and a dense single nucleotide polymorphism map. Journal of Dairy Sciences 91:3225-3236.

Deshaies, R.J., Koch, B.D., Werner-Washburne, M., Craig, E. A and Schekman. R. (1988). A subfamily of stress proteins facilitates translocation of secretory and mitochondrial precursor polypeptides. Nature 332: 800-805. 
Dikmen S and Hansen P.J. (2009). Is the temperaturehumidity index the best indicator of heat stress in lactating dairy cows in a subtropical environment? Journal of Dairy Science 92:109-116.

Erhardt G, Godovac-Zimmermann J, Juszczak J, Prinzen- berg EM, Krick-Saleck H and Panicke, L. (1997). Milk protein polymorphism in Polish and German Red Cattle and the characterization of a new genetic f-lactoglobulin variant. Proceedings of the 48th EAAP Meeting, 25th 28th August. pp 1-7.Vienna, Austria.

Fahlman, A., Storey, J.M and Storey, K.B. (2000). Gene up-regulation in heart during mammalian hibernation. Cryobiology 40(4):332-342.

Farese, J.R., Cases, S and Smith, S.J. (2000). Triglyceride synthesis: insights from the cloning of diacylglycerol acyltransferase. Current Opinion in Lipidology 11:229-234.

Farias, S. T and Bonato, M. C. (2003). Preferred amino acids and thermostability. Genetic and Molecular Resources 2:383-393.

Farrell, H.M, Jimenez-Flores, R., Bleck, G.T., Brown, E.M., Butler, J.E., Creamer, L.K., Hicks, C.L., Hollar, C.M., Ng-Kwai-Hang, K.F and Swaisgood, H.E. (2004). Nomenclature of the proteins of cows' milk sixth revision. Journal of Dairy Sciences 87(6):1641-1674.

Galtier, N and Lobry, J. R. (1997). Relationships between genomic $\mathrm{G}+\mathrm{C}$ content, RNA secondary structures, and optimal growth temperature in prokaryotes. Journal of Molecular Evolution 44: 632-636.

Gaughan, J.B and Cawsell-Smith, A. J. (2015). Impact of climate change on livestock production and reproduction. In: Climate change Impact on livestock: adaptation and mitigation, pp 51-60 ,New Delhi, India.
Gaughan, J. B., Holt, S. M., Hahn, G. L., Mader T. L and Ei-genberg. R. A.. (2000). Respiration rate - is it a good measure of heat stress in cattle? Asian-Australian Journal of Animal Sciences 13(Supplement C): 329-332.

Grisart, B., Coppieters, W., Farnir, F., Karim, L., Ford, C., Berzi, P., Cambisano, N., Mni, M., Reid, S., and Simon, P. (2002). Positional candidate cloning of a QTL in dairy cattle: identification of a missense mutation in the bovine DGAT1 gene with major effect on milk yield and composition. Genome Restoration 12: $222-231$.

Hadecka E, Čitek J, Panicke L, ̌̌ehout V and Hanusova L. (2008). The relation of GH1,GHR and DGAT1 polymorphisms with estimated breeding values for milk production traits of German Holstein sires. Czech Journal of Animal Sciences 53: 238-245.

Hale, C.S., Herring, W.O., Shibuya, H., Lucy, M.C., Lubahn, D.B and Keisler, D.H. (2000). Decreased growth in Angus steers with a short TG-microsatellite allele in the $\mathrm{P} 1$ promoter of the growth hormone receptor gene. Journal of Animal Sciences 78, 2099-2104.

Hall, S.J.G. (2004). Livestock Biodiversity. Genetic Resources for the Farming of the Future. Blackwell, Oxford. England.

Hamza, A. E., Yang , Z. P., Wang , X. L., Chen, R. J., Wu, H. T and Ibrahim, A. I. (2010). The Impact of Kappa Casein Gene Polymorphism on Milk Components and Other Productive Performance Traits of Chinese Holstein Cattle. Pakistan Veterinary Journal 31(2): 153-156.

Hayes B. J., Bowman P. B., Chamberlain A. C., Verbyla K and Goddard M. E. (2009) Accuracy of genomic breeding values in multi-breed dairy cattle Populations. Genetics Selection Evolution 24: 41- 51. 
Hoffmann, I. (2010). Climate change and the characterization, breeding and conservation of animal genetic resources. Animal Genetics 41(1): 32-46.

Jendrzejczyk, M., Grzesiak, W., Szatkowska, I., Dybus, A., Muszynska, $M$ and Zaborski, D. (2011). Association between polymorphisms of CYP19, CYP21 and ER1genes and milk production traits in Black-and-White cattle. Turkey Journal of Veterinary and Animal Sciences 35: 41-49.

Jiang, Z., Michal, J.J., Tobey, D.J., Daniels,T.F., Rule, D.C and Mac Neil, M.D. (2008). Significant association of Stearoyl-CoA desaturase (SCD1) gene with fat deposition and composition in skeletal muscle. International Journal of Biological Sciences 4:345-351.

Kadokawa, H., Blanche D and Martin, G. B. (2006). Plasma leptin concentrations correlate with luteinizing hormone secretion in early postpartum Holstein cows. Journal of Dairy Sciences 89: 3020-3027.

Kaupe, B., Brandt, H., Prinzenberg, E.M and Erhardt, G. (2007). Joint analysis of the influence of CYP11B1 and DGAT1 genetic variation on milk production, somatic cell score, conformation, reproduction, and productive lifespan in German Holstein cattle. Journal of Animal Science 85:11-21.

Kefyalew Alemayehu and Tegegn Fantahun (2012). The Effect of Climate Change on Ruminant Livestock Population Dynamics in Ethiopia. Livestock Research for Rural Development 24 (10).1-10.

Kefyalew Alemayehu and Damitie Kebede (2015). Molecular mechanis ms and the roles of protein in underlying animal adaptation. Global Journal of Animal Science, Livestock Production and Animal Breeding 3 (6): 217-226.
Kefyalew Alemayehu and Addisu Getu (2016). Impacts of climate variability on livestock population dynamics and beed distribution patterns in selected districts of Western Amhara, Ethiopia. Cambridge Journal of Animal Genetic Resources 59: 113-121.

Khatib, H., Maltecca, C., Monson, R.L., Schutzkus, V and Rutledge, J.J. (2009). Monoallelic maternal expression of STAT5A affects embryonic survival in cattle. BMC Genetics 10:13-22.

Kendall, N.R., Gutierrez, C.G., Scaramuzzi, R.J., Baird, D.T., Webb, R and Campbell, B.K. (2004). Directin vivo effects of leptin on ovarian steroid genesis in sheep. Reproduction 128:757-765.

Koohmaraie, M. (1994) .Muscle proteinases and meat aging. Meat Science 36: 93-104.

Kovács, K., Völgyi-Csík, J., Zsolnai, A., Györkös, I and Fésüs, L. (2006). Associations between the AluI polymorphism of growth hormone gene and production and reproduction traits in a Hungarian Holstein-Friesian bull dam population. Archive Tierz 49: 236-249.

Krum, S.A., Womack, J.E and Lane, T.F. (2003). Bovine BRCA1 shows classic responses to geno toxic stress but low in vitro transcriptional activation activity. Oncogene 22: 6032-6044.

Kubiak, E.J., Wyszynska-Koko, J., Wicinska K and Rosochacki, S. (2008). A novel polymorphisms in introns 12 of the bovine calpastatin gene. Molecular Biology and Reproduction 35: 2935.

Liu, W.J., Fang, G.X., Fang, Y., Tian, K.C., Huang, X.X., Yao, X.K., Wang, M., Yu, H., Huang, Y.Z., Xin, J.J., Xin, Y.P., Yu, S.G and Chen, H., (2010). The polymorphism of a mutation of IGF1 gene on two goat breed of China. Journal of Animal Sciences and Veterinary Advancements 9: 790-794. 
Li A, Omura N, Hong SM, Vincent A, Walter K and Griffith M (2010). Pancreatic cancers epigenetically silence SIPI and hypomethylate and overexpress miR-200a/200b in association with elevated circulating miR-200a and miR$200 b$ levels. Cancer Research 70: 5226-5237.

Lord ,G.M., Materese, G., Howard, J. K., Baker, R.J., Bloom, S.R and Lechler, R.I. (1998). Leptin modulates the T-cell immune response and reverses starvation -induced immuno suppression. Nature 394:897-901.

Maak, S., Neumann, K and Swalve, H. H. (2006). Identification and analysis of putative regulatory sequences for theMYF5/MYF6 locus in different vertebrate species. Genetics 379: 141-147.

Marchitelli, C. (2013). Milk fatty acid variability: effect of some candidate genes involved in lipid synthesis. Journal of Dairy Resources 80:165173.

Martin, P., Szymanowska, M., Zwierzchowski, L and Leroux, C. (2002). The impact of genetic polymorphisms on the protein composition of ruminant milk. Reproduction Nutrition and development 42:433-459.

Michael, D.D., Alvarex, I.M., Ocón, O.M., Powell, A.M., Talbot, N.C., Johnson, S.E and Ealy, A.D. (2006). Fibroblast growth factor-2 is expressed by the bovine uterus and stimulates interferontau production in bovine trophectoderm. Endocrinology 147: 3571-3579.

Michal, J. J., Zhang, Z.W., Gaskins, C.T and Jiang, Z. (2006). The bovine fatty acid binding protein 4 gene is significant associated with marbling and subcutaneous fat depth in wagyu $\mathrm{x}$ limousine F2 crosses animal. Genetics 37:400402.

Milanesi, E., Nicoloso, L and Crepaldi, P. (2007 ). Stearoyl CoA desaturase (SCD) gene polymorphisms in Italian cattle breeds . Journal of Animal Breeding and Genetics 125:63-67.

Miyataki, M and Ntambi, J.M. (2003) Role of Stearoyl -coenzyme a desaturase in lipid metabolism. Prostaglandins Leukot essent Fatty Acid 68:113-121.

Mullen, M.P., Lynch, C.O., Waters, S.M., Howard, D.J., Boyle, P.O., Kenny, D.A., Buckley, F., Horan, B and Diskin, M.G. (2011). Single nucleotide polymorphism in the growth hormone and insulin-like growth factor-I genes are associated with milk production, body condition score and fertility traits in dairy cows. Genetics and Molecular Resources 10: 18191830.

Murdoch G.K, Dixon, W.T, Okine, E.K and Christopherson R.J. (2005). Bovine tissue mRNA abundance related to acute cold exposure and acute feeding restriction. Canadian Journal of Animal Sciences 85:157-164.

Nafikov, R. A. (2013). Associations of polymorphisms in solute carrier family 27 , isoform A6 (SLC27A6) and fatty acid-binding protein-3 and fatty acid-binding protein-4 (FABP3and FABP4) with fatty acid composition of bovine milk. Journal of Dairy Sciences 96: 6007-6021.

Nakashima, H, Fukuchi, S and Nishikawa, K (2003). Compositional changes in RNA, DNA and proteins for bacterial adaptation to higher and lower temperatures. Journal of Biochemistry (Tokyo) 133:507-513.

Näslund, J., Fikse, W.F., Pielberg, G.R and Lundén, A. (2008). Frequency and effect of the bovine acyl-CoA: diacylglycerol acyltransferase 1 (DGAT1) K232A polymorphism in Swedish dairy cattle. Journal of Dairy Science 91: 21272134. 
Noguera, J.L., Varona L, Go'mez-Raya L and Sanchez, A. (2003). Estrogen receptor polymorphism in Landrace pigs and its association with litter size performance. Livestock Production Sciences 82:53-59.

Nonaka, S., Hashizume ,T and Kasuya, E. (2006). Effects of intra cerebro ventricular injections of leptin on the release of luteinizing hormone and growth hormone in castrated calves. Animal Sciences Journal 77: 196-200.

Ogorevc, J., Kunej, T., Razpet, A and Dovc, P. (2009). Database of cattle candidate genes and genetic markers for milk production and mastitis. Animal Genetics 40:832-851 .

Oikonomu, G., Angelopoulou, K., Arsenos, G., Zygoyiannis D and Banos, G. (2008). The effects of polymorphisms in the DGAT1, leptin and growth hormone receptor gene loci on body energy, blood metabolic and reproductive traits of Holstein cows. Animal Genetics 40: 10-17.

Oprządek, J., Flisikowski, K., Zwierzchowski, L., Juszczuk-Kubiak, E., Rosochacki, S and Dymnicki, E. (2005). Associations between polymorphism of some candidate genes and growth rates, feed intake and utilization, slaughter indicators and meet quality in cattle. Archive Tierz 48: 81-87.

Pannier, L., Mullen, A.M and Hamill, R.M. (2010). Association analysis of single nucleotide polymorphisms in DGAT1, TG and FABP4 genes and intramuscular fat in crossbred $B o s$ taurus cattle. Meat Science 85:515-518.

Pareek, C.S., Zieba, M., Michno, J., Czaınik, U and Zwierzchowski, L. (2008). Study of SNP $\mathrm{C}:$ Tpolymorphism within the candidate genes for dairy and beef traits in a panel of selected cattle breeds. Journal of Agrobiology 25: 121124.
Paula-Lopes, (2003). Genetic divergence in cellular resistance to heat shock in cattle: differences between breeds developed in temperate versus hot climates in responses of preimplantation embryos, reproductive tract tissues and lymphocytes to increased culture temperatures. Reproduction 125: 285-294.

Paz, A., Mester, D., Baca, I., Nevo, E and Korol, A. (2004). Adaptive role of increased frequency of polypurine tracts in mRNA sequences of thermophilic prokaryotes. Proceedings, National Academic Sciences, USA 101:29512956

Pfister-Genskow, M., H., Eggen Hayes, A and Bishop. M. D. (1997). The leptin receptor (LEPR) gene maps to bovine chromosome 3q33. Mamamalian Genome 8: 227.

Rahbar, R., Rahimi, G., Ansari Pirsaraei, Z and Gholizadeh, M. (2010). Identification of polymorphism in the promoter region of growth hormone receptor (GHR) gene and its association with milk-related traits in Holstein cows. African Journal of Biotechnology 9 (33): 5460-5.

Raynaud, P., Jayat-Vignoles, C., Laforêt, M. P., Levéziel, H and Amarger V. (2005). Four promoters direct expression of the calpastatin gene. Archive Biochemistry and Biophysics 437(1):69-77.

Russell, A.P and Holleman, D. S. (1974). The thermal denaturation of DNA: average length and composition of denatured areas. Nucleic Acid Research 1:959-978.

Schenkel, F. S., Miller, S. P., Ye, X., Moore, S. S and Nkurmah, J.D. (2005). Association of single nucleotide polymorphism in the leptin gene with carcass and meat duality of beef cattle trait. Journal of Animal Sciences 83: 20092020. 
Schenkel,F.S., Miller, S.P., Moore, S.S. Li, C and $\mathrm{Fu}$ A.(2006). Association of a single nucleotide in the leptin and leptin receptor genes with different fat depos in beef cattle. In: Proceedings of the $8^{\text {th }}$ world congress on genetics applied to livestock production pp:1-4, Belo horizontal, Brazil.

Schennink, A., Bovenhuis, H., Léon- Kloosterziel, K. M., Van Arendonk, J. A and Visker, M. H. (2009). Effect of poly-morphisms in the FASN, OLR1, PPARGC1A, PRL and STAT5A genes on bovine milk-fat composition. Animal Genetics 40: 909-916.

Schennink, A., Stoop, W.M. Visker, M.H.P., Heck, J.M.L and Bovenhuis, H. (2007). DGAT1 underlies large genetic variation in milk fat composition of dairy cows. Animal Genetics 38: 467-473.

Silva, A.M., Rios, A.F.L., Ramos, E.S., Lôbo, R.B., Oliveira, H.N and Freitas, M.A.R. (2011). Association between IGF2and CYP21gene polymorphisms and characteristics of economic interest in Nellore cattle. Genetic and Molecular Resources 10: 2140-2147.

Singer, G.A.C and Hickey, D.A. (2003). Thermophilic prokaryotes have characteristic patterns of codon usage, amino acid composition and nucleotide content. Genetics 317:39-47.

Singh, U., Deb, R., Alyethodi, R.R., Alex, R., Kumar, S., Chakraborty, S., Dhama, K and Sharma, A., (2014). Molecular markers and their applications in cattle genetic research: A review. Biomarkers and Genomic Medicine 6: 49-58.

Soria, L. A., Corva, P. M., Branda Sica, A., Villarreal, E. L., Melucci, L. M., Mezzadra, C. A., Papaleo Mazzucco, J., Fernández Macedo, G., Silvestro, C., Schor, A and Miquel, M. C. (2009). Association of a novel polymorphism in the bovine PPARGC1A gene with growth, slaughter and meat quality traits in Brangus steers. Molecular Cell Probes 23: 304-308.

Steinfeld, H., Gerber, P., Wassenaar, T., Castel, V., Rosales, M and de Haan, C. (2006). Livestock's Long Shadow: Environmental Issues and Options. FAO, Rome.

St-Pierre, N. R, Cobanov, B and Schnitkey, G. (2003). Economic losses from heat stress by US livestock industries. Journal of Dairy Science 86: 52-77.

Szatkowska, I., Grzesiak, W., Jedrzejczak, M., Dybus, A., Zaborski, D and Jankowiak, D. (2011). An analysis of CYP19, CYP21and Ergeno types in Polish Holstein-Friesian cows with regard to the selected reproductive traits. Acta Veterinary,Brno 80: 65-71.

Tantia, M.S., Vijh, R.K., Mishra, B.P., Mishra, B., Kumar, S.T.B and Sodhi, M. (2006). DGAT1 and ABCG2 polymorphism in Indian cattle (Bos indicus) and buffalo (Bubalus bubalis) breeds. Veterinary Research 2:32-36.

Thidar, M, H., Yoshida, H., Ito, T., He, M., Inoue, $\mathrm{H}$ and Kuwayama, H. (2008). Combined administration of ghrelin and GHRH synergistically stimulates $\mathrm{GH}$ release in Holstein pre weaning calves. Domestic Animals Endocrinology 34: 118-123.

Thornton, P., Herrero, M., Freeman, A., Mwai, O., Rege, E., Jones, P and McDermott, J. (2007). Vulnerability, Climate change and Livestock - Research Opportunities and Challenges for Poverty Alleviation. International Livestock Research Institute (ILRI), Kenya.

Thornton, P.K., van de Steeg ,J., Notenbaert, A and Herrero, M. (2009). The impacts of climate change on livestock and livestock systems in developing countries: A review of what we know and what we need to know. Agricultural Systems 101: 113-127. 
Verner, J., Humpolicek, P and Knoll, A. (2007). Impact of MYOD family genes on pork traits in Large White and Landrace pigs. Journal of Animal Genetics and Breeding 124: 81-85.

Wang, H.C., Singer, G.A.C and Hickey, D.A. (2004). Mutational bias affects protein evolution in flowering plants. Molecular Biology and Evolution 21:90-96.

Wathes, D.C., Fenwick, M., Cheng, Z., Bourne, N., Llewellyn, S., Morris, D.G., Kenny, D., Murphy, J and Fitzpatrick, R. (2007). Influence of negative energy balance on cyclicity and fertility in the high producing dairy cow. Theriogenology 68: 232-41.

Weikard, R,, Kuhn, C., Goldammer, T., Freyer, $G$ and Schwerin, M. (2005). The bovine ppargc 1a gene: Molecular characterization and association of an snp with variation of milk fat synthesis. Physiol. Genomics 21:1-13.

Wibowo, T.A., Gaskins, C.T., Newberry, R.C., Thorgaard, G.H., Michal, J.J and Jiang, Z. (2008). Genome assembly anchored QTL map of bovine chromosome 14. International Journal of Biological Sciences 4: 406-414.

Yazawa, T., Inaoka, Y., Okada, R., Mizutani, T., Yamazaki, Y., Usami, Y., Kuribayashi, M., Orisaka, M., Umezawa, A and Miyamoto, K. (2010). PPAR-gamma coactivator1alpha regulates progesterone production in ovarian granulosa cells with SF-1 and LRH1. Molecular Endocrinology 24:485-496.

Zhang, H.M., Brown, D.R., Denise, S.K and Ax, R.L. (1993). Rapid communication: polymerase chain reaction-restriction fragment length polymorphism analysis of the bovine somatotropin gene. Journal of Animal Sciences 71: 2276-2279.

Zhu, L., Ke, Y., Shao, D., Cui, Y., Qiao, A., Liu, X., Fang, F and Chang, Y. (2010). Pparã co- activator-1á co-activates steroidogenic factor 1 to stimulate the synthesis of luteinizing hormone and aldosterone. Biochemistry Journal 432: 473-483.

Zumbach, B., Misztal, I., Tsuruta, S., Sanchez, J.P, Azain, M., Herring W, Holl J, Long T and Culbertson, M. (2008). Genetic components of heat stress in finishing pigs: Development of a heat load function. Journal of Animal Science 86: $2082-2088$. 